UDK $577.1: 61$

ISSN 1452-8258

\title{
PREOPERATIVE LYMPHOCYTE-TO-MONOCYTE RATIO VERSUS PLATELET-TO-LYMPHOCYTE RATIO AS A PROGNOSTIC PREDICTOR FOR NON-SMALL CELL LUNG CANCER PATIENTS
}

\author{
PREOPERATIVNI ODNOS LIMFOCITA I MONOCITA U ODNOSU NA ODNOS TROMBOCITA \\ I LIMFOCITA KAO PROGNOSTIČKI PREDIKTOR ZA PACIJENTE OBOLELE \\ OD NEMIKROCELULARNOG KARCINOMA PLUĆA
}

\author{
Haixi Yan, Linling Cai, Shuaishuai Chen, Jun Li \\ Department of Clinical Laboratory, Taizhou Hospital of Zhejiang Province, Taizhou Enze Medical Center(Group), \\ Linhai 317000, Zhejiang Province, China
}

\begin{abstract}
Summary
Background: We investigated the prognostic value of the preoperative lymphocyte-to-mononuclear ratio (LMR) and platelet-to-lymphocyte ratio (PLR) in a large cohort of patients with non-small cell lung cancer (NSCLC).

Methods: Clinical-pathological data from 507 NSCLC patients at Taizhou Hospital of Zhejiang Province between 2010 and 2016 were retrospectively evaluated. X-tile software was used to assess the optimal cutoff levels for LMR and PLR. Univariate and multivariate Cox regression models were used to assess the prognostic factors.

Results: The median follow-up duration after surgical resection was 34.5 months. Patients were stratified into 2 groups by LMR (2.6 and > 2.6) and PLR (179.6 and > 179.6). Our results revealed that lower $L M R(H R=3.163$ (1.821-5.493), $P=0.000)$, age $(H R=2.252$ (1.4123.592), $P=0.001)$, $T$ stage $(H R=3.749$ (2.275-6.179), $\mathrm{P}=0.000), \mathrm{N}$ stage $(\mathrm{HR}=3.106(1.967-4.902), \mathrm{P}=$ $0.000)$, and cut edge ( $H R=3.830$ (1.077-13.618), $P=$ 0.038 ) were considered to be independent indicators for overall survival (OS) of NSCLC patients. For disease-free survival (DFS), age, sex, $T$ stage, $N$ stage, LMR and cut edge were verified to be independent prognostic factors in patients with NSCLC.

Conclusions: In the study cohort, reduced LMR was a robust independent predictor for both OS and DFS in patients with NSCLC who underwent surgical resection.
\end{abstract}

\begin{abstract}
Kratak sadržaj
Uvod: Ispitali smo prognostičku vrednost preoperativnog odnosa limfocita i mononuklearnih jedinjenja (LMR) i odnosa trombocita i limfocita (PLR) u velikoj grupi pacijenata sa nemikrocelularnim karcinomom pluća (NSCLC). Metode: Izvršena je retrospektivna evaluacija 507 NSCLC pacijenata u Taizhou bolnici u provinciji Zhejiang između 2010. i 2016. godine. Korišćen je X-tile softver za procenu optimalnih graničnih nivoa za LMR i PLR. Za procenu prognostičkih faktora korišćeni su univarijatni i multivarijatni Cox regresioni modeli.

Rezultati: Srednje vreme praćenja nakon hirurške resekcije bilo je 34,5 meseci. Pacijenti su stratifikovani u 2 grupe u zavisnosti od LMR $(2,6 \mathrm{i}>2,6)$ i PLR $(179,6 \mathrm{i}>179,6)$. Naši rezultati su pokazali da su niži $L M R(H R=3,163$ $(1,821-5,493), P=0,000)$, starost $(H R=2,252(1,412-$ $3,592), P=0,001)$, $T$ stadijum ( $H R=3,749(2,275-$ 6.179), $P=0,000), N$ faza (HR $=3,106(1,967-4,902)$, $P=0,000)$, i granične vrednost $(H R=3,830(1,077-$ $13,618), P=0,038$ ) smatrani nezavisnim pokazateljima ukupne stope preživljavanja (OS) pacijenata sa NSCLC. Za preživljavanje bez bolesti (DFS), starost, pol, T stadijum, $\mathrm{N}$ faza, LMR i cut-off vrednost su potvrđeni kao nezavisni prognostički faktori kod pacijenata sa NSCLC.

Zaključak: U kohorti studije redukovani LMR je bio robustan nezavisni prediktor i za OS i za DFS kod pacijenata sa NSCLC koji su bili podvrgnuti hirurškoj resekciji.
\end{abstract}

Address for correspondence:

Jun Li

Department of Clinical Laboratory

Taizhou Hospital of Zhejiang Province,

Taizhou Enze Medical Center (Group)

150 Ximen Street of Linhai City, Linhai 317000,

Zhejiang Province, China

Phone: 0576-85226374

e-mail: lijlij3114@163.com 
Keywords: lymphocyte/monocyte, platelet count/lymphocyte, non-small cell lung cancer, prognosis overall survival - disease-free survival

\section{Introduction}

Lung cancer is a malignant tumour that originates in the bronchial mucosa or gland. Common symptoms of lung cancer are cough, dyspnoea, weight loss and chest pain. Symptomatic patients often have the chronic obstructive pulmonary disease (COPD) (1). Lung cancer is the leading cause of cancer death worldwide, with a 5-year survival rate of only $18 \%$ (2). In China, the results of the Third National Cause of Death Sampling Survey in 2008 showed that the incidence of lung cancer increased $26.9 \%$ each year, and lung cancer is the deadliest cancer (3). Based on the biological characteristics, treatments and prognosis of lung cancer, the WHO divides lung cancer into non-small cell lung cancer (NSCLC) (approximately 85\%) and small cell lung cancer. The survival rates of lung cancer are poor overall, but prognosis varies strongly by disease stage at diagnosis. In general, patients with stage I and stage II disease are most likely to be cured by surgery (4). However, a substantial number of patients with NSCLC will experience recurrence or metastasis after surgery. Therefore, potentially useful biomarkers are sought to predict the prognosis of patients with NSCLC after surgery.

Recent reports show that tumour characteristics and the host inflammatory response determine the progression and prognosis of cancer, particularly in NSCLC patients with a background of chronic inflammation (5-7). Inflammatory biomarkers, such as lymphocyte-to-mononuclear ratio (LMR) and platelet-tolymphocyte ratio (PLR), are prognostic factors in colorectal liver-only metastases, breast cancer, thymic epithelial tumours, biliary tract cancer, and ovarian cancer (8-12). Therefore, convenient and simple inflammatory biomarkers associated with risk stratification are important for the prognosis of tumours. In this study, we discussed the prognostic value of the preoperative LMR and PLR in patients with NSCLC after surgery.

\section{Materials and Methods}

\section{Subjects}

A retrospective analysis was conducted in patients with newly diagnosed lung cancer at Taizhou Hospital between January 2010 and March 2017. The inclusion criteria were as follows: 1) patients were aged 18 years or older; 2) NSCLC was diagnosed by histopathology, including adenocarcinoma, large cell carcinoma and squamous cell carcinoma (SCC); 3) no infections of autoimmune diseases were diag-
Ključne reči: limfociti/monociti, broj trombocita/limfocita, nemikrocelularni karcinom pluća, prognoza: opšta stopa preživljavanja - preživljavanje bez bolesti

nosed; 4) no radiotherapy or chemotherapy was performed before surgery; 5 ) radical resection was the surgical method; 6) complete laboratory data were examined before surgery; and 7) patients agreed to follow-up. A total of 507 patients with lung cancer were enrolled: 309 males and 198 females aged 2883 years.

All procedures that followed were in accordance with the ethical standards of the responsible committee on human experimentation (institutional and national) and with the Helsinki Declaration of 1964 and later versions. Informed consent or a suitable substitute was obtained from all patients for inclusion in the study.

\section{Treatment and follow-up}

Each patient was followed up regularly until May 2015 or until death according to the National Comprehensive Cancer Network (NCCN) guidelines. Physical examination, radiologic examination and serum tumour biomarker examination, including examination for carcinoembryonic antigen (CEA) and SCC, were performed every 3 to 6 months for the first 3 years, every 6 months for the fifth year, and then annually. Clearly defined overall survival (OS) and disease-free survival (DFS) were used to represent the prognosis of patients with NSCLC. For patients who were alive at the end of follow-up, OS was defined as the time from the first diagnosis until the final followup. For patients who have died by the end of the follow-up, OS was defined as the time from the first diagnosis until death from any cause. When a patient had a recurrence (whether death or survival), DFS was defined as the time from first diagnosis to the recurrence. When a patient who died was without recurrence, DFS was defined as the time from the first diagnosis to the death. When a patient neither died nor there was recurrence DFS was defined as the time from the first diagnosis to the last follow-up.

\section{Statistical analysis}

SPSS 22.0 was used for statistical analysis. The optimal cut-off values for PLR and LMR were calculated by X-tile 3.6.1 software (13) (Yale University, New Haven, CT, USA). Continuous variables are presented as the median with a range of $25-75 \%$. The relationship between clinical-pathological parameters (features) and these inflammatory biomarkers was determined by the $\mathrm{X}^{2}$ test. To assess relative risk, 95\% confidence intervals $(95 \% \mathrm{Cl})$ of hazard risk (HR) were used as common measures. Significant prog- 
nostic predictors associated with OS and DFS were included to perform multivariate analyses using the Cox proportional hazards regression model. $\mathrm{P}<0.05$ was considered statistically significant.

\section{Results}

\section{Determination of the cut-off value}

OS: The X-tile program was used to determine the optimal cut-off values for PLR and LMR of OS, which were 179.6 and 2.6, respectively (Figure 1). Patients were divided into two groups for further analysis (LMR 2.6 and > 2.6; PLR 179.6 and > 179.6).

DFS: The X-tile program was used to determine critical values for LMR and PLR, which were 5.2 and 184, respectively (Figure 2).

\section{Patient and tumour characteristics}

Among the 507 patients, 309 (60.9\%) were males, and 198 (30.1\%) were females. The median age was 62 (IQR 55-69). The median follow-up of OS was 34.5 months (23.5-47.5 months), with 211 recurrences and 98 cancer deaths. The median follow-up of DFS was 31.0 months (19-42 months). According to the $7^{\text {th }}$ American Joint Committee on Cancer (AJCC) tumour classification, there were 283 (55.8\%) and 224 (44.2\%) T1 and T2-T4 stage distributions of NSCLC cases, respectively, and 412 $(81.3 \%)$ and $95(18.7 \%) \mathrm{N} 0$ and N1-N2 stage distributions, respectively. A total of $407(80.3 \%)$ patients underwent lobectomy, 89 (17.5\%) patients underwent sub-lobar resection, and $11(2.2 \%)$ patients underwent pneumonectomy. The majority of patients $(88.2 \%)$ were confirmed not to have a venous invasion, and $68(11.8 \%)$ were confirmed to have a venous invasion. There were 176 patients who underwent chemotherapy and 34 patients who underwent radiotherapy (Table I).

\section{Baseline patient characteristics according to $L M R$ and $P L R$}

The association of the LMR and PLR with clinical-pathological characteristics is listed in Table II. Our results showed that LMR was significantly associated with sex, smoking history, alcohol history, histology and $\mathrm{N}$ stage. PLR was associated with histology and $N$ stage $(P<0.05)$.

\section{Prognostic value of $L M R$ and PLR}

Univariate analysis of clinic-pathological parameters using the Cox regression model was used to further predict OS and DFS. In univariate analysis, age, sex, smoking history, histology, T stage, N stage, PLR, $L M R$, vascular invasion, neural invasion, pleural inva- sion and cut edge were significantly associated with OS $(P<0.05)$, while age, sex, smoking history, histology, T stage, N stage, LMR, vascular invasion, neural invasion and cut edge were associated with DFS ( $P$ $<0.05$ ). A multivariate Cox regression model was used to investigate clinical-pathological parameters. Our results revealed that low LMR $(H R=3.163$ (1.821-5.493), $P=0.000)$ was associated with reduced OS. Age (HR = $2.252(1.412-3.592), P=$ $0.001), T$ stage $(H R=3.749$ (2.275-6.179), $P=$ $0.000), \mathrm{N}$ stage $(\mathrm{HR}=3.106(1.967-4.902), \mathrm{P}=$ $0.000)$, and cut edge (HR = 3.830 (1.077-13.618), $\mathrm{P}=0.038$ ) were considered to be independent indicators for OS in renal cell carcinoma (RCC) patients. For DFS, age, sex, T stage, N stage, LMR and cut edge were verified to be independent prognostic factors in patients with NSCLC (Table III).

\section{Discussion}

In the development of the molecular biology of tumours, inflammatory responses play a key role in tumour occurrence and progression. We aimed to study the effect of the inflammatory markers LMR and PLR on the survival of patients with NSCLC. This study shows that preoperatively reduced LMR was an independent risk factor for poor clinical outcome in NSCLC patients undergoing surgical resection, but PLR was not significantly related to NSCLC patients.

In different studies, the cut-off values of LMR and PLR were distinct. Guthrie et al. (14) reported different studies using different cut-off values (2.0-5.0). For every cohort of patients, there is no global way to set up a satisfactory general threshold. In 507 patients who underwent NSCLC surgery, we chose X-tile software to determine the best cut-off value for the inflammatory markers of LMR and PLR. Many studies did not include time as a factor when selecting cut-off values, for example, receiver operating characteristics (ROC) curve. The X-tile program chose an exact cutoff in this study. We demonstrated that LMR was correlated with OS or DFS in patients with NSCLC.

In recent decades, the relationship between in ammation and cancer has been hypothesized. Several studies have proven the relationship between cancer and inflammation. In our study, we found that pre-treatment LMR was significantly associated with OS and DFS in patients with NSCLC. Other clinicpathological factors, such as the $\mathrm{T}$ stage, $\mathrm{N}$ stage, and positive surgical margins, were also significantly associated with OS and DFS in patients with NSCLC.

Lymphocytes play critical roles in the antitumour immunity of the host by infiltration into the tumour microenvironment after being triggered by immunologic antitumour reactions.

Previous studies have elucidated that lymphocytes are key factors in immunosurveillance and that 
the occurrence of an immunologic antitumour reaction depends on lymphocytic infiltration into the tumour microenvironment (15-16).

However, systemic inflammation will depress cellular immunity, resulting in lymphocytopenia, which was marked as a decrease in CD4+ helper lymphocytes and an increase in CD8+ suppressor lymphocytes (17). In contrast, tumour-associated macrophages (TAMs) are circulating monocytes that are recruited to tumour sites in excess (18-19). As a result, elevated circulating serum levels of monocytes may re ect increased production of tissue TAMs and high tumour burden and lead to worse survival outcomes. Therefore, LMR and PLR can reflect the body's antitumour status and affect the prognosis of patients with lung cancer.

Several limitations of the present study should be solved. First, this data set includes only surgically resected patients, so this cohort cannot represent patients who have unresectable lung cancer or patients who have not undergone lung cancer surgery. Second, this study includes only patients undergoing radical resection of lung cancer in Taizhou Hospital, with geographical limitations. Third, some of the fam-

\section{References}

1. Simoff MJ, Lally B, Slade MG, Goldberg WG, Lee P, Michaud GC, Wahidi MM, Chawla M. Symptom management in patients with lung cancer: Diagnosis and management of lung cancer, 3rd ed: American College of Chest Physicians evidence-based clinical practice guidelines. Chest 2013; 143: (5 Suppl): e455S-e497S. doi:10.1378/chest.12-2366

2. RL S, KD M, AJ. Cancer statistics, 2015. Ca-A Cancer Journal for Clinicians 2015; 65(1): 5-29.

3. Zeng H, Zheng R, Guo Y, Zhang S, Zou X, Wang N, Zhang L, Tang J, Chen J, Wei K. Cancer survival in China, 2003-2005: A population-based study. International Journal of Cancer 2015; 136(8): 1921-30.

4. Howington JA, Blum MG, Chang AC, Balekian AA, Murthy SC. Treatment of stage I and II non-small cell lung cancer: Diagnosis and management of lung cancer, 3rd ed: American College of Chest Physicians evidencebased clinical practice guidelines. Chest 2013; 143 (5 Suppl): e278S-e313S. doi:10.1378/chest.12-2359

5. Brennan CA, Garrett WS. Gut Microbiota, Inflammation, and Colorectal Cancer. Annual review of microbiology 2016; 70: 395-411. doi:10.1146/annurev-micro102215-095513

6. Cabillic F, Corlu A. Regulation of Transdifferentiation and Retrodifferentiation by Inflammatory Cytokines in Hepatocellular Carcinoma. Gastroenterology 2016; 151(4): 607-15. doi:10.1053/j.gastro.2016.06.052

7. Huang W, Wang S, Zhang H, Zhang B, Wang C. Prognostic significance of combined fibrinogen concen- ilies of patients who died after follow-up refused to follow up on the phone, resulting in the patient not being included in the study, which led to some bias.

In conclusion, the findings in our study suggest that pre-treatment LMR is an independent prognostic biomarker for OS and DFS in NSCLC patients. However, further work is needed to illuminate a more detailed relationship between in ammatory biomarkers and prognosis in NSCLC patients.

\section{Ethical approval}

All procedures performed in studies involving human participants were in accordance with the ethical standards of the institutional and/or national research committee and with the 1964 Helsinki declaration and its later amendments or comparable ethical standards.

\section{Conflict of interest statement}

The authors stated that they have no conflicts of interest regarding the publication of this article.

tration and neutrophil-to-lymphocyte ratio in patients with resectable non-small cell lung cancer. Cancer biology \& medicine 2018; 15(1): 88-96. doi:10.20892/ j.issn.2095-3941.2017.0124

8. Peng J, Li H, Ou Q, Lin J, Wu X, Lu Z, Yuan Y, Wan D, Fang Y, Pan Z. Preoperative lymphocyte-to-monocyte ratio represents a superior predictor compared with neutrophil-to-lymphocyte and platelet-to-lymphocyte ratios for colorectal liver-only metastases survival. OncoTargets and therapy 2017; 10: 3789-99. doi:10.2147/ OTT.S140872

9. Hu RJ, Liu Q, Ma JY, Zhou J, Liu G. Preoperative lymphocyte-to-monocyte ratio predicts breast cancer outcome: A meta-analysis. Clinica Chimica Acta; International Journal of Clinical Chemistry 2018; 484: 1-6. doi:10.1016/j.cca.2018.05.031

10. Janik S, Raunegger T, Hacker $P$, Ghanim B, Einwallner $E$, Mullauer L, Schiefer Al, Moser J, Klepetko W, Ankersmit $\mathrm{HJ}$, Moser B. Prognostic and diagnostic impact of fibrinogen, neutrophil-to-lymphocyte ratio, and platelet-tolymphocyte ratio on thymic epithelial tumors outcome. Oncotarget 2018; 9(31): 21861-75.

11. Zhou LH, Luo XF. Platelet to lymphocyte ratio in biliary tract cancer: Review and meta-analysis. Clinica Chimica Acta; International Journal of Clinical Chemistry 2017; 474: 102-7. doi:10.1016/j.cca.2017.09.006

12. Ma XM, Sun X, Yang GW, Yu MW, Zhang GL, Yu J, Zhang Y, Wang XM. The platelet-to-lymphocyte ratio as a predictor of patient outcomes in ovarian cancer: a meta-analysis. Climacteric: the journal of the Inter- 
national Menopause Society 2017; 20(5): 448-55. doi:10.1080/13697137.2017.1326894

13. Camp RL, Dolled-Filhart M, Rimm DL. X-tile: a new bioinformatics tool for biomarker assessment and outcomebased cut-point optimization. Clinical cancer research : an official journal of the American Association for Cancer Research 2004; 10(21): 7252-9. doi:10.1158/10780432.CCR-04-0713

14. Guthrie GJ, Charles KA, Roxburgh CS, Horgan PG, McMillan DC, Clarke SJ. The systemic inflammationbased neutrophil-lymphocyte ratio: experience in patients with cancer. Critical reviews in oncology/hematology 2013; 88(1): 218-30. doi:10.1016/j.critrevonc. 2013.03.010

15. Hoffmann TK, Dworacki G, Tsukihiro T, Meidenbauer N, Gooding W, Johnson JT, Whiteside TL. Spontaneous apoptosis of circulating $\mathrm{T}$ lymphocytes in patients with head and neck cancer and its clinical importance. Clinical Cancer Research: an official journal of the American Association for Cancer Research 2002; (8): 2553-62.

16. Dragoj M, Bankovic J, Podolski-Renic A, Buric SS, Pesic M, Tanic N, Stankovic T. Association of overexpressed
MYC gene with altered PHACTR3 and E2F4 genes contributes to non-small cell lung carcinoma pathogenesis. J Med Biochem 2019; 38: 188-95.

17. Jovanović $D$, Roksandić-Milenković $M$, Kotur-Stevuljević J, Ćeriman V, Vukanić I, Samardžić N, Popević S, llić B, Gajić $M$, Simon $M$, Simon I, Spasojević-Kalimanovska V, Belić M, Mirkov D, Šumarac Z, Milenković V. Soluble sPD-L1 and serum amyloid A1 as potential biomarkers for lung cancer. J Med Biochem 2019; 38: 332-41.

18. Qian BZ, Li J, Zhang H, Kitamura T, Zhang J, Campion LR, Kaiser EA, Snyder LA, Pollard JW. CCL2 recruits inflammatory monocytes to facilitate breast-tumour metastasis. Nature 2011; 475(7355): 222-5. doi:10. 1038/nature10138

19. Movahedi K, Laoui D, Gysemans C, Baeten M, Stange G, Van den Bossche J, Mack M, Pipeleers D, In't Veld P, De Baetselier P, Van Ginderachter JA. Different tumor microenvironments contain functionally distinct subsets of macrophages derived from Ly6C(high) monocytes. Cancer Research 2010; 70(14): 5728-39. doi:10. 1158/0008-5472.CAN-09-4672

Received: March 27, 2019

Accepted: May 12, 2019 